\title{
"The Ablest Men" \\ American Naval Planning Section London and the Adriatic, 1917-1918
}

\section{Frank A. Blazich, Jr.}

En décembre 1917, la marine américaine a établi la Section de planification navale américaine à Londres, relevant du personnel du vice-amiral William S. Sims, le commandant des forces navales américaines en Europe. Pour Sims, cette section symbolisait les idées et la formation qu'il avait reçues, accompagné de ses planificateurs, au Naval War College aux États-Unis avant la guerre. Malgré l'échec de la Section de planification à mettre en ouvre une opération offensive terre-mer dans l'Adriatique en 1918, son travail à Londres a confirmé auprès du chef des opérations navales la valeur des travaux effectués par le personnel, servant ainsi de modèle à la Division de la planification à Washington après la guerre.

On Christmas Day 1917, Commander Dudley W. Knox and Captain Frank H. Schofield arrived in Liverpool, England aboard the aptly named ocean liner RMS Adriatic. ${ }^{1}$ With Captain Harry E. Yarnell, they formed the nucleus of a new US Navy organization, the American Naval Planning Section London. This small body served as the central component of the staff of Vice Admiral William S. Sims, Commander, US Naval Forces Operating in European Waters. The work of the Planning Section, which was tasked with examining strategic and operational problems, provided Sims and the US Navy with potential solutions to seemingly intractable situations. By late January 1918, the section conceived an aggressive, offensive plan of operations to address one such situation, to break the naval stalemate in the Adriatic and crush the enemy submarine menace wreaking havoc on Allied shipping in the Mediterranean.

Upon his appointment as force commander, Sims prepared a new administrative organization structured around his own experiences, leavened with ingredients

\footnotetext{
${ }^{1}$ The views expressed or implied are solely those of the author and do not necessarily reflect the views of Naval History and Heritage Command, the US Navy, or the Department of Defense. The author wishes to thank Dr. Ryan Peeks, Dr. Greg Bereiter, Mr. Lance Eldridge, Mr. Curtis Utz, Mr. Michael Whitby, Mr. J. Michael Miller, Dr. Roger Sarty, and the anonymous peer reviewers for their assistance and editorial suggestions in the refinement of this paper.
}

The Northern Mariner/Le marin du nord, XXVI, No. 4 (Oct. 2016), 383-406. 


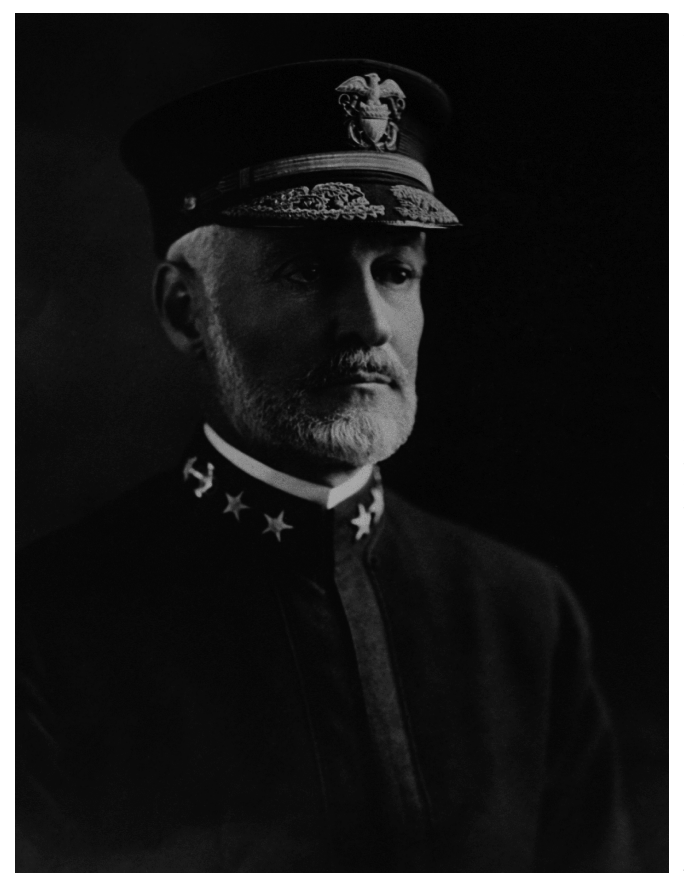

Rear Admiral William S. Sims, circa 19171919. Source: U.S. Naval History and Heritage Command borrowed from the British Admiralty. Revered in some naval circles, controversial in others, Sims steadfastly believed in the pedagogy of the Naval War College, the "long course," the utility of doctrine, and of having a staff of War College trained officers inculcated with this ideology to develop, refine, and promulgate plans and policies to successfully prosecute the war against the Central Powers. His planning section represented an adoption of an equivalent establishment of the British Admiralty, but also the fulfillment of a dream by several War College-trained officers.

The First World War provided an invaluable opportunity for the US Navy to make and test institutional changes in the crucible of war, forging the framework for postwar success. These changes, started at the turn of the century, touched on all facets of naval affairs. This article will focus on institutional education, administrative capability and function. Beginning with an examination of the intellectual origins of the Planning Section through the relationship of the War College and the section's personnel, it will reveal how these factors influenced the development of and campaign for the US plan for a massive combined sea-land offensive operation in the Adriatic in 1918.

The origins of the London Planning Section began in 1911 when Sims received orders to Newport, Rhode Island to attend the Naval War College's new "long course." Before the long course, the War College as it developed at the turn of the century engaged in peacetime war planning through use of the staff system. Students in the four-month summer conference focused their efforts around several problems, with each student preparing solutions for discussion by the assembled body of staff and students. The four-month conference, however, proved limiting to the depth and breadth of knowledge an attendee could obtain. In 1910, Captain William McCarty Little managed to impress upon Rear Admiral Reginald F. Nicholson, Chief of the Bureau of Navigation, the need for an expanded sixteen-month course, and in October 1911 four students from the summer conference began the long course. The 
four initial students were Captains William S. Sims and Josiah McKean, Commander Yates Stirling, Jr., and Captain Earl H. Ellis of the Marine Corps. ${ }^{2}$

The long course" coincided with the blending of new and refined pedagogical methods. From the late 1890s into the new century, the War College's curriculum continuously increased in sophistication with its lectures, reading lists, and utilization of war games for instruction and refinement of tactical and strategic naval problems. In 1912, these attributes merged in the curriculum with the introduction of the "applicatory system." Adopted in part from the Army War College, this threepart system revolved around the "estimate of the situation," writing of orders, and evaluating the orders via war games or staff rides. The estimate of the situation provided a consistent approach to evaluate a military or naval problem and ascertain a course of action through a series of steps and decisions. A student needed to derive a clear mission statement, consider probable enemy strength and intentions, assess their own forces' strength, capabilities, and disposition, evaluate the effectiveness of possible courses of action, and then reach decisions regarding a final course of action. Once completed, the student drafted orders in a standardized format and then war gamed his work to provide a theoretical "test" for evaluation. "Combining the applicatory system, the estimate, order form, and map manoeuvre made possible the creation of doctrine in the Navy," concludes historian Ronald Spector. ${ }^{4}$

The long course and applicatory system made an indelible impression upon Sims. In the wake of a presidential reprimand for his infamous Guildhall speech of December 1910, Sims initially viewed the War College as an escape, writing his wife "It may even be that things will blow over to such an extent that I may get some duty that I would like better than the War college-something in closer touch with practice and less on the theoretical side." By March, Sims altered course, explaining "I would much prefer going to the War College, as that is the experience I need most - a study of the theory of strategy and tactics - and I would like to have that before going to sea again. All this from a strictly professional point of view . .

\footnotetext{
2 John B. Hattendorf, B. Mitchell Simpson, III, and John R. Wadleigh, Sailors and Scholars: The Centennial History of the US Naval War College (Newport, RI: Naval War College Press, 1984), 54-56, 74-76; Ronald Spector, Professors of War: The Naval War College and the Development of the Naval Profession (Newport, RI: Naval War College Press, 1977), 71-74, 121-23; United States Naval War College (NWC), "Register of Officers, 1884-1979" (Newport, RI: Naval War College Press, 1975), 17. Before 1904, the four-month period was referred to as a course and then post 1904 as a conference.

${ }^{3}$ Members of the Staff, US Naval War College, "Notes on the Applicatory System of Solving War Problems, with Examples Showing their Adaptation of the System to Naval Problems" United States Naval Institute Proceedings, XXXVIII: 3 (September 1912), 1011-36; Spector, Professors, 74-82, 117-19; Hattendorf, et al., Scholars, 39-42, 69-73; John B. Hattendorf, "Technology and Strategy: A Study in the Professional Thought of the US Navy, 1900-1916" Naval War College Review, XXIV: 3 (November 1971), 30-31.

4 Spector, Professors, 119.

5 William S. Sims to Anne Sims, 31 January 1911, Box 6, William Sowden Sims Papers (WSS), Naval Historical Foundation Collection, Manuscript Division, Library of Congress, Washington, DC (LC). Regarding the Guildhall speech and its aftermath, see Elting E. Morison, Admiral Sims and the Modern American Navy (Boston, MA: Houghton Mifflin Co., 1942), 276-285.
} 
. ." Arriving in Newport in late May to begin the summer conference, Sims entered the long course that September, completing his work the following year. ${ }^{7}$

Over sixteen months, Sims voraciously consumed the War College curriculum. He inculcated himself with the applicatory system and the conference method of open discussion. "Any man who compares certain opinions he brought to the Naval War College at the beginning of the long course with those he took away at the end, must realize the unrivalled advantages of full and free discussion; and must recognize the extreme improbability that his own undiscussed opinions are always infallible," he later recorded. ${ }^{8}$

Most critical for Sims was the "understanding he gained of the principles and meaning of military

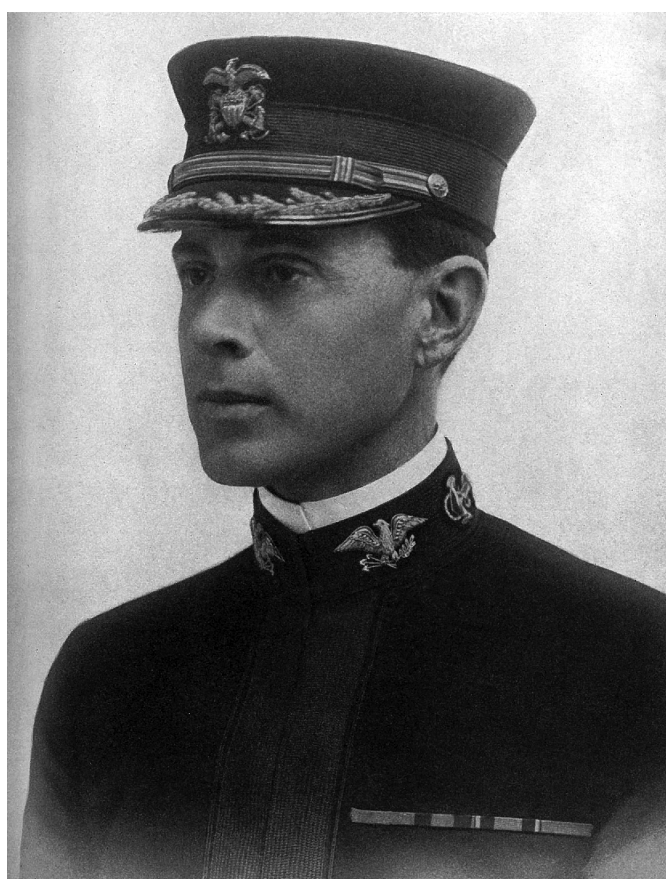

Captain Dudley W. Knox, circa 1918.

Source: U.S. Naval History and Heritage Command doctrine." As functionally defined within the navy at the onset of the First World War, doctrine is a composition of beliefs or teachings reasoned from principles, which can serve as a general guide to the application of mutually accepted principles to govern actions. In the arena of naval warfare with emerging technologies and complex manoeuvres and operations, Lieutenant Commander Dudley W. Knox articulated how doctrine could "furnish a basis for prompt and harmonious conduct by the subordinate commanders of a large military force, in accordance with the intentions of the commander-in-chief, but without the necessity for referring each decision to superior authority before action is taken. More concisely stated the object is to provide a foundation for mutual understanding between the various commanders during hostile operations." $" 10$

Through the study of historical examples, Knox detailed how foreign military organizations recognized the need for this mutual understanding, notably in the war

\footnotetext{
6 Sims to Anne Sims, 6 March 1911, Box 6, WSS, LC.

7 Memorandum, "Admiral William Sowden Sims, United States Navy, Retired, Re: Service of," 23 December 1932, biographical file for William Sowden Sims, Naval History and Heritage Command (NHHC), Washington, DC.

${ }^{8}$ William S. Sims, "Naval War College Principles and Methods Applied Afloat" United States Naval Institute Proceedings, XLI:2 (March-April 1915), 385.

9 Morison, Sims, 290.

${ }^{10}$ Dudley W. Knox, "The Role of Doctrine in Naval Warfare" United States Naval Institute Proceedings, XLI:2 (March-April 1915), 334.
} 


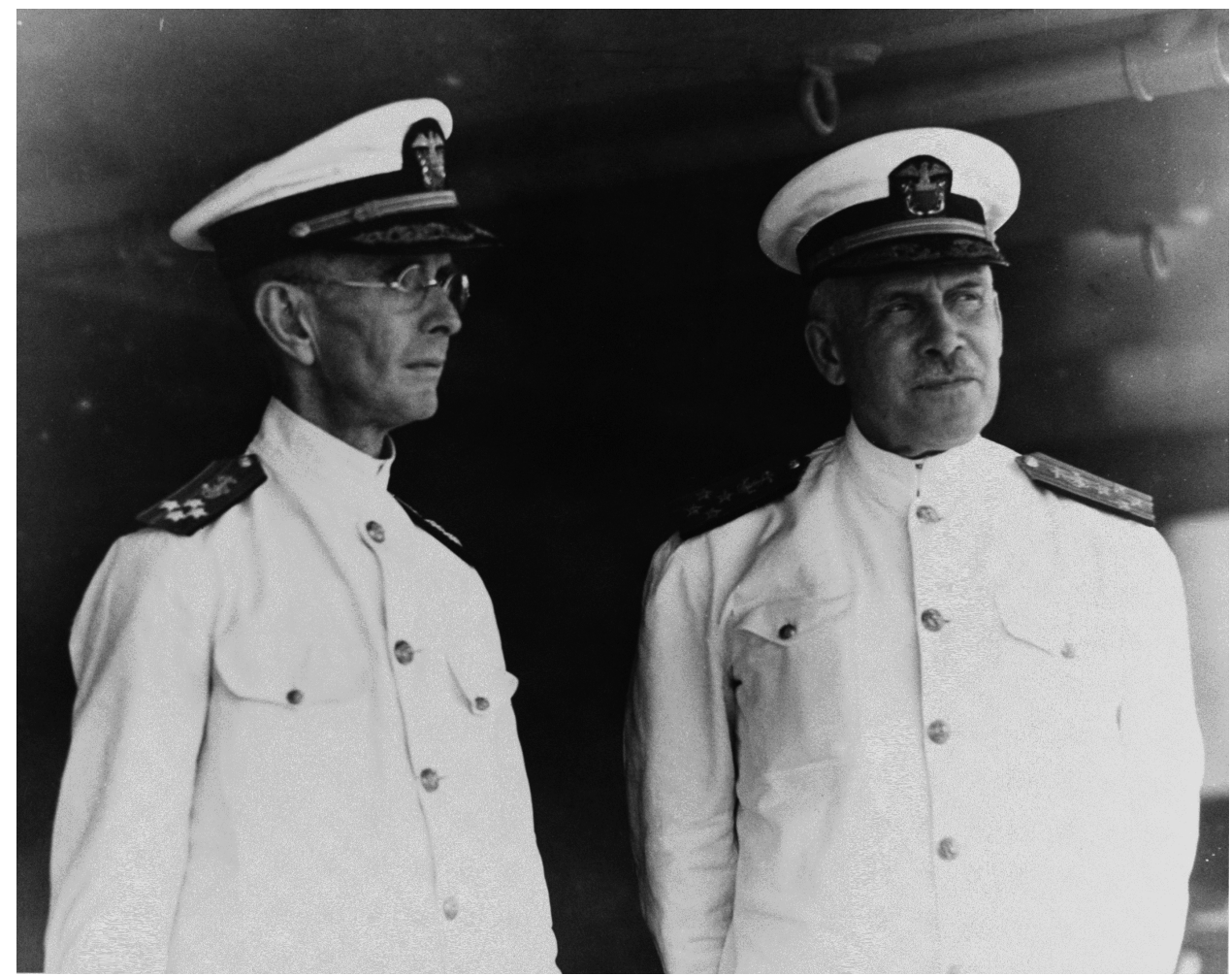

Admiral Frank H. Schofield, left, and Admiral William V. Pratt, right, on board the battleship USS California (BB-44), February 1931. Source: Naval Historical Foundation, Admiral William V. Pratt Collection, U.S. Naval History and Heritage Command

doctrines of Germany and France as informed by the Napoleonic era and the recent outbreak of war in Europe. In the arena of naval warfare, Admirals Horatio Nelson, Wilhelm von Tegetthoff, and Tōgō Heihachirō provided models of doctrinal employment in comparison with Admirals Pierre-Charles Villeneuve, Zinovy Rozhestvensky, and Carlo Pellion di Persano. ${ }^{11}$

For Sims, fresh from command of the battleship Minnesota, doctrine enabled him to understand the battle space beyond the command bridge or the War College's game boards. Herein lay the tool to command and wield a vast force with decisive effect.

With doctrine, Sims found himself drawing closer intellectually to several War College attendees and staff members. These men included Knox and Commanders William V. Pratt and Frank H. Schofield. ${ }^{12}$ The War College's conference method,

\footnotetext{
${ }^{11}$ Ibid., 335-45.

${ }^{12}$ Gerald E. Wheeler, Admiral William Veazie Pratt, US Navy: A Sailor's Life (Washington, DC: Navy History Division, Department of the Navy, 1974), 70-71; "Rear Admiral Frank Herman Schofield, US Navy, Retired, Inactive, Deceased, Re: Service of,” 24 February 1942, biographical file for Frank Herman Schofield; "Captain Dudley Wright Knox, US Navy, Retired, Re: service
} 
"where ideas, facts, and logic were of greater importance than rank and name, allowed an officer to add a significant increment to his 'service reputation,", argues historian Gerald E. Wheeler. ${ }^{13}$ In the long course, Sims studied tactics, strategy, policy, and logistics and applied his study in preparation of situation estimates and gaming of his solutions, all while being guided to derive general principles from his studies and discussions among peers. ${ }^{14}$ His peers, especially Knox and Pratt, would become Sims's "gang at the college," bound by a common belief that they could "indoctrinate the navy with the principles of naval warfare," thereby bringing the War College methodology out of Newport and applying it to the fleet at large. ${ }^{15}$ What was needed to accomplish this was a laboratory where abstract theory could transform into practical application.

From June 1913 to October 1915, the Atlantic Torpedo Flotilla served as the testing ground for Sims's modern ideas. In March 1913, Sims received news that Navy Secretary George von L. Meyer approved his assignment to the flotilla command. Writing to Aid for Operations Rear Admiral Bradley A. Fiske, Sims acknowledged that flotilla command afforded the opportunity to "develop the strategical and tactical employment of these vessels in connection with the operations a great battle fleet." ${ }^{\prime 6}$ Sims set two terms to Fiske for accepting the assignment: provision for an adequate command staff and a flagship capable of manoeuvres and service as a floating schoolhouse where all the commanding officers could meet to discuss flotilla problems. ${ }^{17}$ The staff, Sims asserted, "should be composed of officers who have been trained in a knowledge of war," and specifically requested Pratt as chief of staff with Knox as his aide. Sims confidently declared, "I am sure that something useful could speedily be accomplished." ${ }^{18}$ Fiske agreed to the terms and in June Sims, Knox, and Pratt arrived at the New York Navy Yard to develop the warships and the torpedo armament of the flotilla into an effective fighting force. ${ }^{19}$

From his flagship Dixie, Sims brought the War College out to the flotilla and the US Atlantic Fleet. Using the conference method, all commanding officers brought their collective knowledge to bear in an open setting to discuss and determine solutions and policies. Sims sought to break the mould of previous commands where the "old man" was the fountain of knowledge and wisdom. The regular open discussions among commanding officers enabled the men to tackle the primary matters of developing torpedo tactics and doctrine. First, using a large game board and ship models aboard the Dixie - and later the light cruiser Birmingham - and

of," 2 October 1941, biographical file for Dudley Wright Knox; “Admiral William Veazie Pratt, US Navy, Retired, Deceased," 9 July 1948, biographical file for William Veazie Pratt, NHHC.

Knox graduated from the long course in 1913. NWC, "Register," 18.

${ }_{13}^{13}$ Wheeler, Pratt, 71.

${ }^{14}$ Hattendorf, et al., Scholars, 79.

${ }_{15}$ Sims to Anne Sims, 1 March 1913, Box 6, WSS, LC.

${ }^{16}$ Morison, Sims, 292-93.

${ }^{17}$ Sims, "Principles," 384.

${ }_{18}^{18}$ Sims to Bradley A. Fiske, 3 March 1913, Box 57, WSS, LC.

${ }^{19}$ Hattendorf, et al Scholars, 88-89; Wheeler, Pratt, 72-73. 
then testing the gamed tactics at sea against the battleship fleet, a refined doctrine emerged. This practical application of the War College training subsequently produced the first naval doctrine developed and used in the navy. Contrasting its impact with previous flotilla practices, doctrine made a successful attack possible upon receipt of a thirty to forty-word radio message, rather than a 1,200-word or longer written order and accompanying blueprint. The flotilla's performance in manoeuvres proved exemplary and provided proof to the value of the doctrine and War College methods to the US Atlantic Fleet. ${ }^{20}$

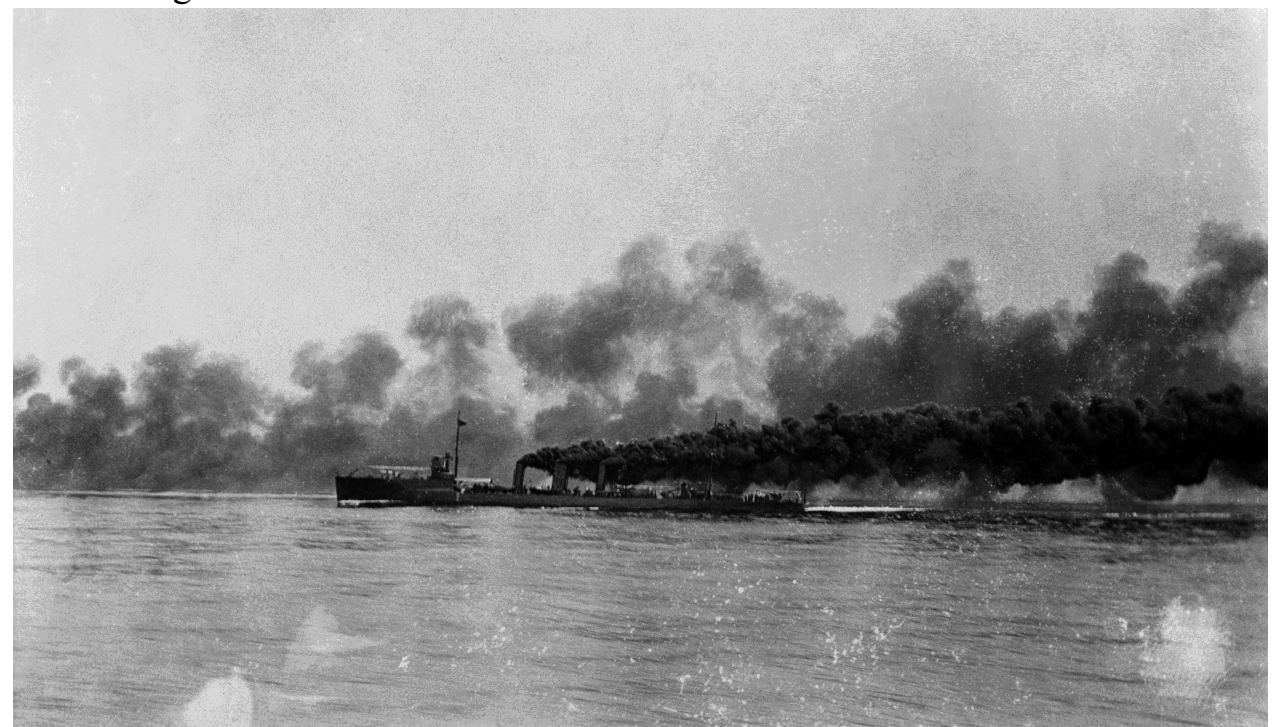

Destroyer laying smoke, possibly USS Walke (DD-34) of the U.S. Atlantic Fleet Torpedo Flotilla, circa 1914. Source: photograph courtesy of Jim Kazalis, U.S. Naval History and Heritage Command

Knox was the mastermind behind the doctrine itself. His research on doctrine enabled him to codify and elucidate the results of the flotilla conferences into what he called a "tentative doctrine" in 1914. ${ }^{21}$ A severe ulcer forced him to leave the flotilla for the Office of Naval Intelligence in November 1914, but the flotilla continued to refine his work and distributed a finalized version of the doctrine to all

\footnotetext{
20 Morison, Sims, 294-302; Wheeler, Pratt, 73-74; Sims, "Principles," 392, 401-2; Spector, Professors, 124; Hattendorf, et al., Scholars, 89; Sims to Anne Sims, 8 March 1914; Sims to Anne Sims, 10 March 1914; Sims to Anne Sims, 12 March 1914, Box 7; Sims to Hutchinson I. Cone, 12 November 1915, Box 22, WSS, LC. The flotilla under Sims's command produced three future chiefs of naval operations: Pratt, Harold R. Stark, and Ernest J. King. Navy Department, Register of the Commissioned and Warrant Officers of the United States Navy and Marine Corps, 1 January 1915 (Washington, DC: Government Printing Office, 1915), 267-68.

${ }^{21}$ Atlantic Fleet Torpedo Flotilla, "Flotilla Tentative Doctrine," 3 March 1914, Box 21 WSS, LC; Sims to Fiske, 19 February 1914, Box 7, WSS, LC.
} 
commanders in $1915 .^{22}$ That same year, Knox published a seminal article in the United States Naval Institute Proceedings entitled "The Role of Doctrine in Naval Warfare," where he cogently defined, explained, and articulated doctrine with reference both to the flotilla's work and the War College's pedagogy. With war engulfing Europe, Knox raised the issue of warfighting, arguing that "To reach the ultimate goal of war efficiency we must begin with principles, conceptions and major doctrines, before we can safely determine minor doctrines, methods, and rules." Determining such matters consequently produces "a 'conception' of war which furnishes a point of origin, without which we are as uncertain of our bearings as a vessel in a fog," he concluded. ${ }^{23}$ The navy-should it enter the European conflict - increasingly required professional, War College-trained officers actively practicing the foundational doctrine and principles from which victory would emerge.

In April 1917, Sims, now the president of the Naval War College, secretly sailed to England with his aide, former flotilla torpedo expert, and recent War College graduate Lieutenant Commander John V. Babcock. Washington ordered Sims to meet with the Allied admiralties, examine the present naval situation and determine

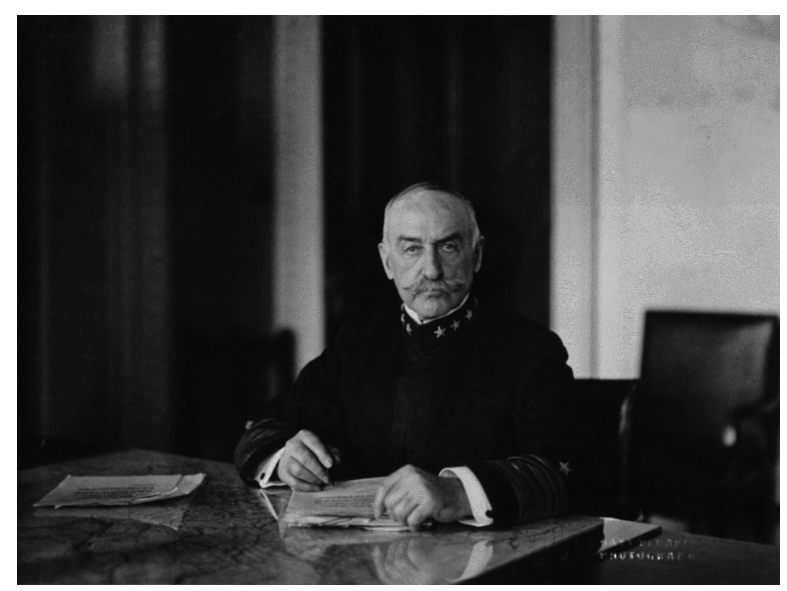

Admiral William S. Benson, Chief of Naval

Operations, circa 1916-1919. Source: U.S. Naval History and Heritage Command

\footnotetext{
${ }^{22}$ Sims to Fiske, 19 February 1914, Box 7; Atlantic Fleet Torpedo Flotilla, "Flotilla Tentative Doctrine," 3 March 1914, Box 21; Sims to Edward W. Eberle, 13 December 1915, Box 22; Dudley W. Knox to Sims, 25 August 1914; Sims to Knox, 28 August 1914, Box 69, WSS, LC; biographical file for Knox, NHHC; Morison, Sims, 295-96.

${ }^{23}$ Knox, "Doctrine," 352-53.
} 
the most expeditious means for the nation to support their war efforts. ${ }^{24}$ Prior to leaving the Navy Department, Chief of Naval Operations (CNO) Admiral William S. Benson, reminded Sims not to let the British deceive or mislead him as "it is none of our business pulling their chestnuts out of the fire." ${ }^{25}$ After arriving in Liverpool and meeting with First Sea Lord Admiral Sir John Jellicoe, Sims learned the true gravity of the German submarine campaign against British shipping. In the first of many cablegrams to the Navy Department, Sims recommended the expedited dispatch of all destroyers and small surface craft to British waters in order to combat submarines. Within weeks of his arrival, he received orders on 29 April detaching him from the War College presidency and placing him in command of all American destroyers, auxiliaries, and tenders operating from British bases, with the first destroyers arriving at Queenstown, Ireland on 4 May. ${ }^{26}$

The day after his position changed from official observer to active commander, Sims began requesting additional staff. He wanted War College and torpedo flotilla men, particularly his old staff. On 30 April, Sims requested Pratt as his chief of staff, together with other officers, and then continued to ask for Pratt throughout May into July. ${ }^{27}$ Pratt himself, despite expressing a desire for frontline service, explained to Sims a higher purpose for remaining at the new Office of the Chief of Naval Operations (OPNAV), mainly that Benson believed

that [a] group of men having the same general ideas, the same War College training are necessary here to back up a situation which at any time may need the united efforts of such a band. . . . It is at present the one combat body of men in positions where they can influence policy, who think alike, are indoctrinated with the War College principle, and who are trying as far as power will let them, to carry on this war playing no favorites but sending men and forces where we think they can best do the work. ${ }^{28}$

\footnotetext{
${ }^{24}$ Senate Committee of Naval Affairs, Naval Investigation, 66th Cong., 2d sess., 1921, I: 268-69; NWC, "Register of Officers, 1884-1979," 22.

${ }^{25}$ Naval Investigation, I: 269.

${ }^{26}$ William S. Sims, The Victory at Sea (New York: Doubleday, Page and Co., 1920), 7-9; William N. Still, Jr., Crisis at Sea: The United States Navy in European Waters in World War I (Gainesville, FL: University of Florida Press, 2006), 14-15; Naval Investigation, I: 29-42; Josephus Daniels to Sims, 29 April 1917, Box 644, Record Group 45: Records Collection of the Office of Naval Records and Library, Subject File, 1911-1927 (RG45), National Archives and Records Administration, Washington, DC (NARA); Joseph K. Taussig, The Queenstown Patrol, 1917: The Diary of Commander Joseph Knefler Taussig, US Navy, ed. William N. Still, Jr. (Newport, RI: Naval War College Press, 1996), 19-21.

${ }^{27}$ Sims to Knox, 9 July 1917, Box 69, WSS, LC; Walter H. Page via Sims to Robert Lansing for Navy Department, 30 April 1918, Box 644, RG45, NARA; Naval Investigation, I: 203-14; Sims to Daniels, 8 May 1917; Sims to Daniels, 12 May 1917; Sims via Page for Daniels, 16 May 1917; Sims to OPNAV, 22 May 1917, Box 3, William Shepherd Benson Papers, Manuscript Division (WSB), LC; Wheeler, Pratt, 104. Sims requested Pratt on seven occasions.

${ }^{28}$ William V. Pratt to Sims, 27 May 1917, Box 643, RG45, NARA.
} 
Certainly Sims could empathize with Pratt's position, particularly as the creation of the CNO position and OPNAV in 1915 represented new, untested entities, much like his own command. And although the first CNO, Benson, never attended the long course, he had attended a summer conference and recognized War College graduates' immense value to his office. Furthermore, Pratt, after becoming the Benson's chief of staff (assistant chief of naval operations) in June 1917, like Sims, used his career connections to build up OPNAV staff with the ablest men available. ${ }^{29}$

Informed of Pratt's unavailability, Sims cabled Secretary of the Navy Josephus Daniels of his need for a chief of staff and at least two War College-educated assistants. He suggested and received Captain Nathan C. Twining as chief of staff, a 1915 graduate of the War College and college staff member when Sims assumed the presidency in $1917 .{ }^{30}$ Sims repeatedly requested more personnel, specifically "men of special experience, training and ability," emphasizing "they be selected from the younger and more progressive type and preferably graduates of the War College." ${ }^{31}$ What Sims failed to realize — or chose not to - was the dearth of officers, War College graduates, and men trained and experienced with staff work. This shortage made it difficult for Pratt and Benson to meet the demands for the rapidly expanding navy. But with the exigencies of war in the waters of Europe, Sims arguably considered his staffing needs of higher priority than those thousands of miles away in Washington. ${ }^{32}$ His requests were considered by the Navy Department and with the lead actor in London the stage was set for the navy to implement a series of rapid developments to strengthen its presence in Europe.

The growing mission of the US Navy in Europe drove its overall expansion. On 26 May, Sims received temporary promotion to vice admiral, followed up weeks later on 14 June by Daniels designating Sims as "Commander, United States Naval Forces Operating in European Waters." Although the senior American naval officer in Europe, Sims essentially served as an administrator, with no operational authority. Benson and Pratt considered Sims's functions and authority as akin to Benson's assistant as "the London representative" of OPNAV. Conversely, he built his forces and specifically his administrative headquarters in accord with his War College training. If the torpedo flotilla served as the laboratory, Sims's headquarters in London and the war in European waters would represent the practical application of his experiments on a grand scale. Sims raised his flag as force commander aboard the tender Melville at Queenstown on 11 August. He outlined his disposition of forces as constituting "a Task Force of the Atlantic Fleet," and clarified the lines of

\footnotetext{
${ }^{29}$ Mary Klachko with David F. Trask, Admiral William Shepherd Benson: First Chief of Naval Operations (Annapolis, MD: Naval Institute Press, 1987), 31; Wheeler, Pratt, 96, 104, 114.

${ }^{30}$ Naval Investigation, I: 206; Sims to Daniels, 5 July 1917, Box 4, WSB, LC; OPNAV to Office of Naval Intelligence, 6 July 1917, Box 644, RG45, NARA; NWC, "Register," 21-22; Naval Investigation, I: 213-14.

31 Sims via State Department to OPNAV, 9 July 1917; Sims to Woodrow Wilson, 10 July 1917, Box 349, RG45, NARA.

${ }^{32}$ Wheeler, Pratt, 104-05; Still, Crisis, 33-35.
} 
communications for his command and its London office, thereafter known as "Simsadus." 33

Across the Atlantic that same day, President Woodrow Wilson delivered an address aboard the battleship Pennsylvania at Yorktown, Virginia to Commander-inChief Admiral Henry T. Mayo and officers of the US Atlantic Fleet. The president used a whimsical anecdote to describe the submarine menace and to articulate his policy for the navy. He declared "We are hunting hornets all over the farm and letting the nest alone. None of us knows how to go to the nest and crush it, yet ... I am willing to sacrifice half the navy Great Britain and we together have to crush that nest, because if we crush it, the war is won." 34 In the president's estimation, victory would come from aggressive, offensive action against enemy submarine bases, not seemingly passive convoying where the enemy might never be encountered.

This expressed opinion of operational effort did not reflect the majority opinion in a debate which raged for months among senior American officials. The General Board had advised Daniels on 5 April "not [to] depend upon the defensive but prepare for and conduct a vigorous offensive." 35 Sims had also repeatedly cabled Washington to combat submarines through convoys in alignment with the Admiralty. Washington, however, did not support this perspective, with convoying considered a passive approach. ${ }^{36}$ On 30 April, Pratt informed Sims that "At present the one and only offensive is against the submarines," adding "The purely defensive role must be subordinated," with the two main areas of offensive action seen as the North Sea and Mediterranean. ${ }^{37}$ Knox also wrote to the admiral, sharing his belief that "every effort should be made towards actual offensive operations against the submarine rather than relying upon the more nearly defensive methods." 38

Crushing the hornets' nest or hunting them around the farm produced a somewhat heated exchange between Sims and Washington. Washington desired aggressive action in the face of apparent British malaise and timidity, which they believed the strongly Anglophile Sims had imbibed. The Navy Department remained sceptical of the British Admiralty, notably in regard to British calls for material assistance without providing any concrete plans or information regarding

\footnotetext{
33 Wilson to Sims, 26 May 1917; Daniels to Sims, 14 June 1917, Reel 1; United States Naval Forces Operating in European Waters, Force Instruction No. 1: Organization and Communications, 11 August 1917, Reel 2, ME-11, Naval Department Library (NDL); "The Office of Naval Operations During World War," Box 42, WSB, LC; Naval Investigation, I: 1203; Still, Crisis, 23, $25-28,37$.

${ }^{34}$ Document marked "Confidential Copy Not to be Published in Any Form, The President, to the Officers of the Atlantic Fleet," 11 August 1917, Reel 2, ME-11, NDL.

${ }^{35}$ David F. Trask, Captains and Cabinets: Anglo-American Naval Relations, 1917-1918

(Columbus, MO: University of Missouri Press, 1972), 58.

${ }^{36}$ Trask, Cabinets, 64-66; Klachko, Benson, 74.

37 Pratt to Sims, 30 April 1917, Box 643, RG45, NARA.

38 Knox to Sims, 11 June 1917, Box 69, WSS, LC.
} 
the disposition of American resources. ${ }^{39}$ Daniels sent Sims a declaration of American naval policy, including an "emphasis on offensive operations." $40 \mathrm{Sims}$, however, held fast to his fervent belief that convoying provided the most viable offensive antisubmarine action, and reiterated to Washington his requirement for a proper staff in order to provide additional information to ostensibly support this position. ${ }^{41}$ Privately, Sims confided to Knox his concurrence with the principle of offensive actions as he "always advocated interposing our armed forces directly between the submarine and the submarine's objective." 42 This correspondence was only days after Sims questioned Pratt about the lack of support from the US Navy for convoy duty and the Navy Department's apparent conclusion that British policies were unwise.

Without complete confidence in the situation, Washington-with Sims's support - opted to send a mission to Great Britain to discover the facts for themselves. In late August, Mayo and his staff travelled to London to attend an international naval conference. The actual conference of 4-5 September, in which Sims joined Mayo, largely remained a discussion of generalities but Mayo found the meetings useful for inter-allied coordination. The trip's most valuable contributions seem to have been greater communications between the British and American naval establishments and between Sims and the Navy Department, specifically Benson. ${ }^{43}$

Sims refined his argument for additional staff with Benson. Benson expressed his surprise that neither Sims nor the Admiralty had produced any plan of operations. Sims countered that the Admiralty had offered to join in any plan meeting with the approval of the Allied admiralties and war departments. ${ }^{44}$ Regarding staff, Sims desired his personnel to work closely with the Admiralty with no administrative responsibility. Sims thought "it will be necessary that not less than five officers be made available, in addition to the Chief of Staff, who should be the head of this organization. Such a Staff could, and would, work in close cooperation with a recently established Planning Staff of the British Admiralty."45 Sims suggested predominantly War College-educated up-and-coming younger officers as the staffers, notably captains Frank H. Schofield, Luke McNamee, Yates Stirling,

\footnotetext{
39 Michael Simpson, ed., Anglo-American Naval Relations, 1917-1919 (Brookfield, VT: Gower Pub. Co., 1991), 76-77, 95-96; Simpson, Relations, 118-19.

${ }^{40}$ Still, Crisis, 17-18; Daniels to Sims, 9 July 1917, Reel 1, ME-11, NDL.

${ }^{41}$ For debate of convoy operations versus attacking naval bases, see Trask, Cabinets, 72-73, 132-

33; Still, Crisis, 409-410, 638n9; Wheeler, Pratt, 116-17; Morison, Sims, 356-63, 412-16.

${ }^{42}$ Sims to Knox, 9 July 1917, Box 69; Sims to Pratt, 3 July 1917, Box 22, WSS, LC.

43 Klachko, Benson, 76-84; Trask, Cabinets, 127-33, 145-57; Daniels, Diaries, 189-92; Still, Crisis, 73-74; Henry T. Mayo to Benson, 8 September 1917, on "Report of International Naval Conference held in London, 4-5 September 1917; and kindred matters," Box 5, WSB, LC; Simpson, Relations, 95-98; A. Temple Patterson, ed., The Jellicoe Papers: Selections from the Private and Official Correspondence of Admiral of the Fleet Earl Jellicoe, II, 1916-1935 (London: Navy Records Society, 1968), 203-08.

${ }^{44}$ Benson to Sims, 24 September 1917; Sims to Benson, 28 October 1917, Box 49, WSS, LC.

45 Sims to Benson, 9 October 1917, Box 49; Sims to Pratt, 10 October 1917, Box 79, WSS, LC; Sims to Benson, on "Need for an increased staff for the Force Commander," 23 October 1917, Box 662, RG 45, NARA.
} 
Jr., William S. Pye, and Harry E. Yarnell, among others. This staff, working closely with the Admiralty's new planning staff, would make development of plans for aggressive operations against the submarine menace possible. ${ }^{46}$

In November, Benson joined an American mission to Europe led by President Wilson's trusted advisor, Edward M. House. Benson's visit to Europe lifted the veil of uncertainty with the Admiralty and clarified the Navy Department's policy with his host. The CNO's interaction with senior British naval officers proved successful, and both parties shared a desire to develop plans together for operations. This mutual acceptance of joint planning resulted in the establishment of the American Naval Planning Section London. ${ }^{47}$ On 16 November, Daniels wired Benson that "After thinking carefully ... . [I] feel that it would be [an] advantage if we have a permanent War Staff in England as part of the plans Department of Admiralty." 48 The idea found a welcome reception from the CNO. Benson replied strongly:

that the British are not prepared now to offer definite plans of their own for our consideration. From my observations and after careful consideration I believe that such plans satisfactory to both countries cannot be developed until we virtually establish the strictly planning section for joint operations here in order that the personnel thereof may be in a position to obtain latest British and other allied information and to urge as joint plan such plans as our estimate and policies may indicate ... . The officers detailed for this study should come here fully imbued with our national and naval policies and ideas. Then with the intimate knowledge they can obtain here . . . they will be in a position to urge upon British any plan that promises satisfactory results. $^{49}$

Benson, acting on the guidance of Pratt, recommended that the secretary order Schofield and Knox to report to Sims, with a third officer to be selected after his return. Daniels approved Benson's proposal and Knox and Schofield soon had orders for London. ${ }^{50}$

\footnotetext{
${ }^{46}$ Sims to Benson, 23 October 1917, Box 662, RG 45, NARA; Sims to Benson, 28 October 1917, Box 49, WSS, LC.

${ }^{47}$ Still, Crisis, 74-75; Josephus Daniels, The Cabinet Diaries of Josephus Daniels, 1913-1921, ed. by E. David Cronon (Lincoln, NE: University of Nebreaska Press, 1963), 212, 218, 212, 226-27; Klachko, Benson, 82-83, 86; Trask, Cabinets, 166-69; Simpson, Relations, 104-17; Statement of Admiral William S. Benson, the Chief of Naval Operations, made in London on November 1917, on "Naval Policy of the United States"; "Record of the Activities of Admiral Benson while Serving as a Member of the American Mission Headed by Colonel House," undated, Box 42, WSB, LC; Benson to Pratt, 18 November 1917, Box 662, RG45, NARA.

${ }^{48}$ Daniels to Benson, 16 November 1917, Box 662, RG45, NARA.

${ }^{49}$ Benson to Daniels, 19 November 1917, Box 658, RG45, NARA; Still, Crisis, 44, 531n112; Navy Department, Office of Naval Intelligence, Historical Section, The American Naval Planning Section London (Washington, DC: Government Printing Office, 1923), 10, 489.

${ }^{50}$ Pratt to Benson, 20 November 1917, Box 658, RG45, NARA.
} 


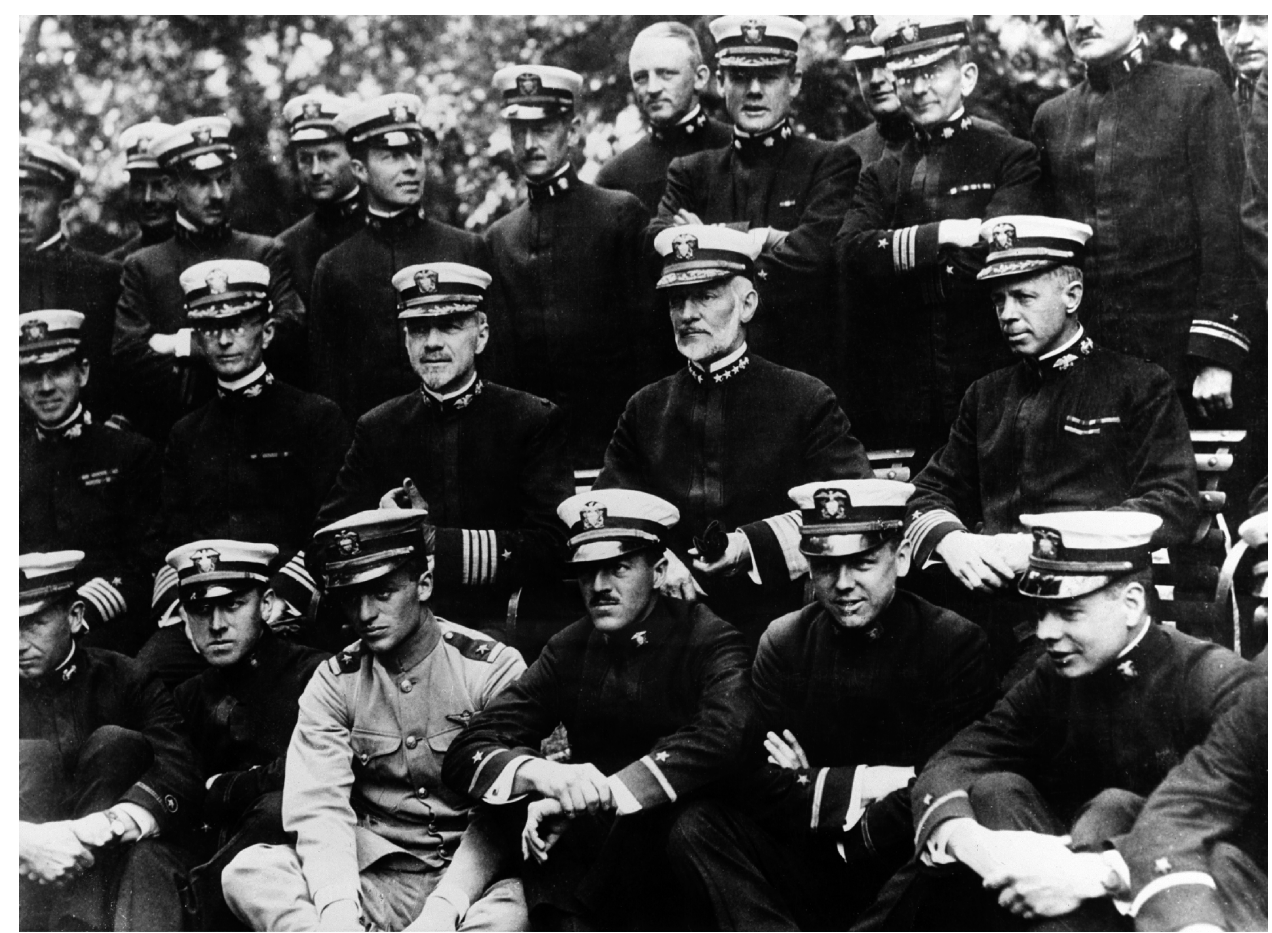

Vice Admiral William S. Sims with members of his staff, circa mid-1918. Seated in the second row, from left to right: Captain Dudley W. Knox, Captain Frank H.

Schofield, Captain Nathan C. Twining, Vice Admiral Sims, and Captain Harry E. Yarnell. Source: U.S. Naval history and Heritage Command

Concurrent with the House mission, Benson and other Allied naval representatives established the Allied Naval Council, under which coalition plans for victory would be developed. In Paris on 29 November, representatives from the French, British, American, Italian, and Japanese navies met to establish the Allied Naval Council with a mission to watch over the general conduct of the naval war, ensure coordination of efforts at sea, and oversee development of all scientific operations connected with the conduct of the war. The council would also make recommendations to enable the Allied governments to make informed decisions, although individual responsibilities of chiefs of staff and commanders in chief of naval operations remained unchanged. ${ }^{51}$ Together, the Planning Section and Allied Naval Council equipped Sims with the means to present the Allies with plans for aggressive offensive operations.

The Planning Section developed swiftly in late December 1917 and early January 1918. It stood up on 26 December consisting of Knox, Yarnell, and

\footnotetext{
${ }^{51}$ Summary memorandum of naval conference held at Ministry of Marine, Paris, 29 November 1917; meeting minutes of Paris Conference, 29 November 1917, Box 42, WSB, LC.
} 
Schofield. ${ }^{52}$ The three men reported to Twining, who served as the ex officio leader of the section with Schofield as its working head. Devoid of administrative duties, the officers devoted all their time to surveying operations, discovering mistakes, suggesting improvements, and preparing plans for future operations, essentially delivering the force commander a "continuous Estimate of the Situation." 53 Sims could not have been more pleased with the section. He felt it consisted of "the ablest men in the navy." 54

The Americans worked as a unit, considering questions provided by Sims or OPNAV. The memoranda they produced neatly mirrored the War College methodology. The section received office space at the Admiralty with the British Plans Division which greatly facilitated joint discussions and occasional joint drafting of solutions to problems. American planners had access to British intelligence for use in the drafting of their memoranda and refined their thinking with their British counterparts. What influence the Americans had on the British plans, however, is in the words of the Planning Section "difficult to estimate." The section certainly built cooperation and facilitated greater communication between the British and American naval staffs, although the American proposals were rarely "frankly accepted" and in regards to antisubmarine operations, "There appeared constantly to be a strong and almost unanimous reluctance on the part of the British command to accept these doctrines. In the British Plans Division, however, they were favorably indorsed. . .."55 In a weekly report to Benson, Sims wrote that the Planning Section's influence upon the Admiralty "has been noticeably affecting the methods of work of the Plans Division of the Admiralty and affecting the opinions of the Admiralty Naval Staff." The Planning Section's chief value, in Sims's opinion, "has been in its tendency to establish mutual understanding as to methods of thought on military questions as between ourselves and the Admiralty."

As the Planning Section examined numerous problems, early efforts focussed on developing a plan for offensive operations in the Adriatic. Few areas caused as much consternation among the Allies as containing and destroying the submarine threat in the Mediterranean from the Kaiserliche und Königliche (k.u.k) Kriegsmarine of the Austro-Hungarian Empire and Kaiserliche Marine of the

\footnotetext{
52 Simsadus, "Information Bulletin No. 7," 14 December 1917; Simsadus, "Information Bulletin No. 16," 26 December 1917; Simsadus, "Information Bulletin No. 17," 27 December 1917, Box 652, RG45, NARA; biographical file for Schofield; biographical file for Knox; biographical file for Yarnell, NHHC.

${ }^{53}$ Sims, Victory, 253; Nathan C. Twining, "regarding Planning Section of Admiral Sims's Staff," 3 January 1918, Box 662, RG45, NARA.

${ }^{54}$ Sims to Anne Sims, 16 January 1918, Box 9, WSS, LC.

55 Navy Department, Planning, 10-11, 491-92.

56 Sims to Benson, 16 August 1918, Reel 5, ME-11, NDL; Still, Crisis, 44-45; Twining, "regarding Planning Section of Admiral Sim's Staff," 3 January 1918; Sims to Benson, on "Planning Section of Force Commander's Staff," 21 January 1918, Box 662; Sims to Joel R.P. Pringle, 17 January 1918, Box 645, RG45, NARA. Sims himself believed the planning section's work was “exerting a very marked influence upon the various members of the Admiralty." Sims to Benson, 7 March 1918, Box 49, WSS, LC.
} 
German Empire. Austro-Hungarian and German submarines operated from bases in the Adriatic, principally at Pola and Cattaro. Italy declared neutrality at the onset of hostilities in 1914, and the British and French agreed that the latter would control the general direction of the naval war in the Mediterranean. Although the French desired attacks on Pola and Cattaro, they recognized both operations as equally difficult.

The Treaty of London, signed on 26 April 1915, brought Italy into alliance with the Triple Entente and changed the dynamics of the naval war in the Adriatic. Under the terms of the treaty, the Italians agreed to join forces with France, Great Britain, and Russia while the French and British agreed to render assistance to Italy until the k.u.k. Kriegsmarine was either destroyed or peace concluded. The Allies also promised Italy substantial postwar territorial acquisitions, particularly Dalmatia and the Dodecanese. ${ }^{57}$ Strategically, the Austro-Hungarians under Grand Admiral Anton Haus and later Rear Admiral Miklos Horthy, recognized that a defensive strategy of maintaining the fleet-in-being at Pola kept the Italians on notice, as both powers were almost equally matched in dreadnoughts. The Italian Regia Marina, under the command of Vice Admiral Paolo Count Thaon di Revel, opted to pursue a defensive strategy, as survival of the Italian navy and victory over the Austro-Hungarians would result in absolute Italian military mastery of the Adriatic and economic benefits via territorial annexations in the postwar period. ${ }^{58}$

In 1915, German submarines appeared in the Adriatic and by September 1916, Kaiserliche Marine U-boats were inflicting significant losses on shipping in the Mediterranean. Uncoordinated Italian, French, and British responses did little to counter the submarine offensive. The British established a barrage at the Strait of Otranto, a choke-point, in 1915, maintained by a series of net drifters with small guns and depth charges along with Italian and French destroyers for defensive support. A handful of enemy submarines fell victim to the barrage, but the majority slipped through the nets into the open Mediterranean to range freely. In 1917, German submarine operations increased in intensity with the reoccurrence of unrestricted submarine warfare, accounting for almost 30 percent of all Allied tonnage lost in April. Allied antisubmarine efforts that year proved disappointing. Only two German submarines were sunk in the Mediterranean in $1917 .{ }^{59}$

American entry into the war offered additional resources in the so far one-sided fight against enemy submarines in the Mediterranean. On 16 August 1917, the cruiser Sacramento arrived at Gibraltar followed a day later by the cruiser Birmingham, the first American forces in the Mediterranean. Additional American ships arrived in the coming days to work with Allied forces as part of the overall

\footnotetext{
${ }^{57}$ Great Britain, Parliamentary Papers, Miscellaneous No. 7: Agreement between France, Russia, Great Britain, and Italy, signed at London, April 26, 1915 (London: HMSO, 1920).

${ }^{58}$ Paul G. Halpern, The Naval War in the Mediterranean, 1914-1918 (Annapolis, MD: Naval Institute Press, 1987), 6-7, 26-33, 85-98; Trask, Cabinets, 228.

${ }^{59}$ Halpern, Mediterranean, 107-10, 151-259, 278-85, 307-39; Paul G. Halpern, The Battle of the Otranto Straits: Controlling the Gateway to the Adriatic in World War I (Bloomington, IN: Indiana University Press, 2004), 1-34.
} 
antisubmarine patrol effort. ${ }^{60}$ Five destroyers from the Asiatic Fleet also steamed from the Philippines via the Suez Canal, arriving at Gibraltar on 20 October to augment the cruisers. $^{61}$ The United States was at peace Austria-Hungary, and consequently, American ships avoided venturing farther into the Mediterranean on the off-chance of encountering an Austro-Hungarian submarine which might have caused an international incident. ${ }^{62}$

For the Italians seeking additional military resources, the American entry into the region proved enticing. Their delegates approached Mayo in September about acquiring American destroyers, and in November the Italian ambassador asked Daniels for fuel oil, sea mines, submarine chasers, aircraft and personnel for air bases to use for raids on Austro-Hungarian submarine bases. Daniels asked Benson why Italy wanted all the resources, recognizing the request, "if granted, commits us to a policy of active participation." ${ }^{63}$ But in the background of this request lay the overwhelming Italian defeat at the Battle of Caporetto (24 October - 19 November 1917) and fear by the Allies of Italy's internal stability. Ambassador Thomas N. Page in Rome lobbied Wilson for a declaration of war against Austria-Hungary for morale purposes and his arguments impacted the decision to declare war on 7 December. $^{64}$

When the Planning Section commenced work in early January, they prepared an "Estimate of the General Naval Situation" for the entire war. The planners concurred that the basic naval mission in the war was "to further a successful decision on land," with naval forces therefore oriented to obtain command of the sea. ${ }^{65}$ Among the general conclusions for the entire European war, the section decided to develop future plans for concentrated air attacks on enemy submarine bases in the Adriatic, plans for attacks with surface vessels against enemy Adriatic bases, and study the use of mine barrages in the Adriatic and Aegean. To achieve success with the plans, the US and her Allies needed to coordinate their political and military efforts, and the Adriatic was one theatre poised for decisive action. A coalition-led attack on the enemy naval bases in the Adriatic would free assets for the Allied cause throughout the Mediterranean, notably to use against the Ottoman Empire and the Dardanelles. Knox, Schofield, and Yarnell concluded that "the entire naval problem of the Mediterranean and Adriatic is a major problem in which the United States and the Allies are all greatly interested." 66

\footnotetext{
${ }^{60}$ Henry B. Wilson to Sims, on "report of Operations Patrol Squadron based on Gibraltar, August 17th-25th," 25 August 1917, Reel 18, ME-11, NDL. Rear Admiral Wilson in turn would be replaced in January 1918 by Rear Admiral Albert P. Niblack as commander of US naval patrol forces based on Gibraltar. Niblack to Sims, 4 January 1918, Reel 19, ME-11, NDL.

61 Sims to SENAFLOAT, Gibraltar, 23 October 1917, Reel 2, ME-11, NDL.

${ }^{62}$ Halpern, Mediterranean, 377.

63 Mayo to Benson, 8 September 1917, on "Report of International Naval Conference held in London, 4-5 September 1917; and kindred matters"; Daniels to Benson, 20 November 1917, Box 5, WSB, LC; Daniels, Diaries, 239; Halpern, Mediterranean, 377, 401-07.

64 Trask, Cabinets, 230-31; Still, Crisis, 484; Daniels, Diaries, 248.

65 Navy Department, Planning, 39.

${ }^{66}$ Navy Department, Planning, 37, 48, 50, 57.
} 
The Planning Section's 30 January 1918 memorandum titled the "Adriatic Situation" provided Sims and the United States with an original plan for aggressive offensive operations. This planning focus fulfilled the desires of Wilson, Daniels, and Benson to "crush the nest," by taking the naval war directly to the source-at least in the Mediterranean - by attacking submarines in main and auxiliary bases and preventing the boats' escape. The planners considered the value of an offensiveminded attitude, concentration of effort, importance of unity of command, and enemy and Allied morale. Examining the assets of the k.u.k. Kriegsmarine, its various naval bases - specifically Cattaro - wireless stations, fuel resources, and enemy intentions, the Allies were presented with four general courses of action: reduce enemy bases in the Adriatic, destroy enemy naval forces in their bases, destroy enemy naval forces at sea, and contain enemy naval forces in the Adriatic.

The planners settled on a fifth option, titled "destruction of enemy bases," which amalgamated elements from all four general courses of action. An Allied naval force would seize and secure a naval base between Curzola and Sabbioncello Peninsula. Simultaneously, a landing party of Marines would raid the railroad in the vicinity, destroying tunnels, bridges, and occupying a position astride the railroad as long as possible before falling back to hold defensive positions on the peninsula. Meanwhile, a large force of surface combatants would sail to Curzola to interrupt completely all traffic of surface vessels between the northern Austro-Hungarian bases and Cattaro. Additional landing forces would seize the islands of Lizza, Brazza, Meleda, Lesina, Lagosta, Gazza, and Pelagosa, fortifying the latter three to provide refuge for light vessels under attack. With the islands seized, a mine barrage would be laid from the Italian coast at Gargano Head to Curzola. A massive surprise raid on Cattaro led by US pre-dreadnoughts supported by minesweepers and destroyers from Allied nations would sink all enemy vessels in the harbor with subsequent air attacks targeting enemy submarines. Special mine fields designed as submarine traps would be planted in the vicinity of Cattaro subsequent to the raid and antisubmarine forces would thereafter commence patrolling the southern Adriatic. Finally, a strong force of surface vessels would be held in readiness at Corfu to prevent enemy cruisers from Pola or Cattaro from breaking out of the Adriatic. The planners calculated the overall effort required four dreadnoughts, ten pre-dreadnoughts, twenty light cruisers, destroyers, trawlers and sweepers, submarines, listening groups of submarine chasers, mine layers, transports, auxiliaries, and 30,000 troops. ${ }^{67}$

Sims commenced work on securing the necessary approval from Washington. Cabling the details to OPNAV, he noted its acceptance would require an American contribution of 25,000 sea mines, "as many destroyers as can be spared from other areas," five Virginia-class or Connecticut-class battleships, and thirty-six submarine chasers with tender. ${ }^{68}$ Without department approval, Sims presented the plan to the

\footnotetext{
${ }^{67}$ Navy Department, Planning, 59-75; Planning Section to Sims, 10 March 1918, Box 23, WSS, LC.

${ }^{68}$ Sims to OPNAV, 2 February 1917, Box 415, RG45, NARA.
} 
Allied Naval Council at its meeting in Rome on 8-9 February. No decisions were reached and the subject was tabled for the London meeting in March. Sims believed that cooperation of all the other governments could be secured while recognizing that the burden of operations would fall on the Americans and British, with US Marines identified for the landing force. ${ }^{69}$ OPNAV cabled approval for study and consideration of the broad plan on the grounds it would strengthen the Allied position in the Mediterranean and supplemented plans for the mine barrage in the North Sea. $^{70}$

Major opposition to advancing the plan came from Revel and Italian naval politics. During the Rome meeting, he presented preliminary notes on the strategic situation in the Adriatic. Revel contended that the k.u.k. Kriegsmarine would not come out to fight lest it risk total destruction and loss of its Adriatic maritime denial capability. "An offensive by the Allied Fleet in the Adriatic would be an unpardonable error, and the only manner of destroying the Austrian Fleet is to make it the unceasing target for bombardment by air," he concluded. Furthermore, as the nation most influenced by the Adriatic, it remained an Italian theatre necessitating Italian control. $^{71}$

Sims should not have been surprised by Revel's stance. On his travel to Rome for the meeting, the French naval representatives shared their opinion of the general attitude of the Italian Ministry of Marine. "This attitude, in a word, is that the Italians are now, and always have been, distinctly opposed to any energetic naval action in the Adriatic," he reported to Benson. Sims observed that the postwar situation seemed to occupy Italian thinking, and that American involvement did not please them. "It is a little difficult to account for this feeling except upon the assumption that they dread the influence of America in European politics," Sims wrote, as Wilson would undoubtedly influence the postwar settlements. ${ }^{72}$ Taking into account the political dimension, Revel's assessment arguably is sound. The stasis between the k.u.k. Kriegsmarine and the Regina Marina in the Adriatic placed the onus for national military success principally on the Italian Army engaged with its Austro-Hungarian counterparts along the nation's northern borders. From the perspective of the Treaty of London, the Italian political climate, and morale of the populace, opting for the "long game" of stasis may have aggravated the Allies but best served the needs of Italy and Revel.

Revel reviewed the proposed American plan for the Adriatic, raising issues over the American contribution. ${ }^{73}$ Italian scepticism cannot entirely be attributed to intransigence on their strategic position. American forces in the Mediterranean did

\footnotetext{
69 Sims to OPNAV, 14 February 1918, Box 546, RG45, NARA; Still, Crisis, 493; Halpern, Mediterranean, 435-36.

${ }^{70}$ OPNAV to Sims, 10 February 1918, Box 415, RG 45, NARA.

71 Vice Admiral Paolo Count Thaon di Revel, "Preliminary Notes by Italy for the Commission in Rome, February 8th, 1918," in Allied Naval Council, "Appendix No. 50: Report of the Commission which met in Rome on February 8th and 9th, 1918," 18 February 1918, Box 545, RG45, NARA.

72 William S. Benson to William S. Sims, 15 February 1918, Box 49, WSS, LC.

73 Charles R. Train to Sims, 15 February 1918, Box 23, WSS, LC.
} 
not exactly represent the Navy Department's finest. The five destroyers from the Asiatic Fleet literally were the service's first five destroyers ever built and well past their prime. Rear Admiral Albert P. Niblack, commander of US naval patrol forces based on Gibraltar, commented that they "were condemned in the Philippines as being unsafe to go out of sight of land," adding "Every time they go out I feel a bit anxious until they get in again." ${ }^{.74}$ Coast Guard cutters and armed yachts together with older cruisers completed Niblack's flotilla of "historical relics" which constantly required repair. ${ }^{75}$ Looking at those forces, Revel's doubts of America commitment to the plan seemed warranted. Sims still considered the Italian resistance, specifically Revel, to be more political than anything else. With the Planning Section welcoming the addition of a new member, Colonel Robert $\mathrm{H}$. Dunlap, USMC, and working smoothly with the Admiralty and the Allied Naval Council, Sims remained confident that the plan for action in the Adriatic would gain approval. $^{76}$

The Allied Naval Council discussed the American plan in depth in London from 12-14 March. Before the meeting, the Admiralty Plans Division and the US Planning Section both agreed to the essentials of the plan: seizing a base at Sabbioncello, laying a mine barrage from Gorgona to Curzola, and denying Cattaro to enemy submarines. ${ }^{77}$ For the initial seizure of a base at Sabbioncello, Sims cabled OPNAV asking that steps be taken to ready a force of 20,000 Marines with all equipment and armament should the plan be adopted, forces then available in the Western hemisphere. ${ }^{78}$ Before the meetings, OPNAV requested input from the various war councils prior to rendering a judgment, observing that great logistic demands of the Western Front precluded discussion of any other moves, "regardless of how attractive its local aspects may be . . . without full discussion by all parties concerned."79

Advancement of the plan now rested on securing Allied support. The French and Japanese supported the American proposal. The Italians and Revel essentially only had two objections: placing an Italian admiral as commander-in-chief and removal of a statement: "Enemy operations in the Adriatic so far both of his surface vessels and his submarines, have resulted in making the Adriatic practically an Austrian lake in which no Allied Naval operations of importance are undertaken." ${ }^{80}$ Revel

\footnotetext{
74 Niblack to Sims, 18 March 1918, Box 76, WSS, LC.

75 Niblack to Sims, 29 March 1918, Box 76, WSS, LC; Simpson, Relations, 429-34.

76 Sims to Anne Sims, 15 February 1918; Sims to Anne Sims, 16 March 1918, Box 9; Sims to Charles R. Train, 23 February 1918, Box 23; Sims to Benson, 28 February 1918, Box 49, WSS, LC; Senate Committee on Naval Affairs, Awarding of Medals in the Naval Service, 66th Cong., 2d sess., 1920, 424. Dunlap joined the Planning Section as a lieutenant colonel on 6 March 1918 and received promotion while on the Planning Section.

77 Navy Department, Planning, 137-38.

78 Sims to OPNAV, 8 March 1918, Box 546, RG45, NARA; Halpern, Mediterranean, 437-38.

${ }^{79}$ OPNAV to Sims, 11 March 1918, Box 660, RG45, NARA.

${ }^{80}$ Allied Naval Council, "Memorandum No. 49: The Situation in the Adriatic as Affecting the Mediterranean and the Decisions that should be taken to further successful war," prepared by United States, 30 January 1918, Box 545, RG45, NARA; Halpern, Mediterranean, 438-39.
} 
referenced similar plans developed by the Italian Naval Staff and proposed that all nations send personnel to Rome to examine and discuss them. Sims agreed to the Rome visit, disagreed that the Adriatic was an Italian question since the enemy submarines affected all the Allies, and stated that whoever took command was irrelevant "so long as he was a fighter." Differences aside, the Allies approved the principle of the American plan and unanimously agreed to undertake operations as soon as possible to sever the enemy's north - south base communications. Since this work involved seizing certain islands in the Adriatic with the cooperation of land forces, the admirals needed to secure the approval of the military representatives of the Supreme War Council. ${ }^{81}$

The senior Allied admirals met with the Allied armies' military representatives on $14 \mathrm{March}$. In the half hour meeting, the four general officers from France, Great Britain, Italy, and the United States concluded that the matter needed to be considered in regard to the entire allied war front. The limited scope of the military operations made it impossible to foresee the number of forces eventually required. Even though US Marines would be the initial ground forces, any reinforcements would have to be Italian of which none were available. The plan did not appear favourable to the generals although they assured the admirals they would study the matter carefully. ${ }^{82}$ Sims viewed the entire affair as "very unsatisfactory" and the situation on the Western Front made the present project consideration impracticable. ${ }^{83}$ Nonetheless, the Italian naval attaché informed OPNAV that his government was inclined to support the plan. ${ }^{84}$

War on land soon brought an end to any hopes for the naval plan's implementation. On 21 March, German General Erich Ludendorff's spring offensive commenced on the Western Front in France. Plans for the Adriatic were set aside. Unsurprisingly, on 8 April the Supreme War Council concluded that no military forces should be diverted to the Adriatic project but that project study should continue for possible future execution, circumstances permitting. ${ }^{85}$

When the Allied Naval Council met in Paris from 26-27 April, Sims reached agreement with the other admirals to provide the Supreme War Council with more detailed information. All parties agreed that a select subcommittee would assemble in Rome from 15-21 May to examine existing Italian plans and draw out a

\footnotetext{
${ }^{81}$ Allied Naval Council, "Memorandum No. 81: Adriatic,” 28 March 1918, Box 546, RG45, NARA.

${ }^{82}$ Allied Naval Council, "Memorandum No. 81: Adriatic," 28 March 1918, Box 546, RG45, NARA; Frank H. Schofield, "Naval Strategy and Tactics with Special Reference to Seacoast Fortifications," 8 January 1923, Box 21, Dudley Wright Knox Papers, Manuscript Division, LC; Sims to Benson, 25 March 1918, Box 49, WSS, LC; Trask, Cabinets, 246-47.

${ }^{83}$ Sims to OPNAV, 14 March 1918, Box 546; Sims to Benson, 14 March 1918, Box 415, RG45, NARA; Sims to Benson, 25 March 1918, Box 6, WSB, LC.

${ }^{84}$ OPNAV to Sims, 16 March 1918, Box 415, RG45, NARA.

${ }^{85}$ Sims to OPNAV, 19 April 1918, Box 546, RG45, NARA.
} 
preliminary report for the council. ${ }^{86}$ Yarnell and Dunlap, assisted by the navy's attaché in Rome, Commander Charles R. Train, served as the United States representatives. Discussions focused on seizing the base at Curzola and Sabbioncello. A naval raid on Cattaro was ignored as the Italians instead raised concern with the low American force estimates to seize the Sabbioncello peninsula. They also proved unwilling to support any initiative and disagreements broke out over the timing of the emplacement of the mid-Adriatic mine barrage. ${ }^{87}$

Over 11-12 June, Washington's effort to achieve aggressive offensive operations in the Adriatic ended. During the fourth meeting of the Allied Naval Council in London, the committee reviewed the reports from the Rome subcommittee and decided "it would not be practicable at the present time to provide the Military personnel required, while the collection of the necessary materials would also be a matter of some months." With these circumstances in hand, no purpose could be served placing the matter before the Supreme War Council or preparing detailed plans ${ }^{88}$ Cabling OPNAV, Sims concluded: "In view of the strong opposition of Italy, the more passive opposition of France and the present military situation, I deem it inadvisable to push our plan further at present . . . . The execution of the proposed Adriatic project may be considered at a future date should circumstances warrant." ${ }^{89}$ With the unavailability of ground forces, the Planning Section prepared a new, purely naval estimate of the general situation in the Mediterranean. ${ }^{90}$

Months of work failed to provide the plans Wilson and senior American naval leaders desired to "crush the hornets' nest." No amount of intellectual energy could overcome the dual hammer blows of a massive German ground offensive in northern France and Italian intransigence to alter its postwar strategic and political goals. The Planning Section's able men could not outwit or outmaneuvre the deeply ingrained suspicions and nationalistic animosities between the Italians, French, and British. The plan itself did not benefit from its optimistic objectives juxtaposed with immense logistical complexity. The majority of resources and efforts would be American, but. Italy doubted US resolve. The US Navy had sent its weakest, most antiquated naval assets to Gibraltar for patrol and escort duties.

\footnotetext{
${ }^{86}$ Allied Naval Council, "Memorandum No. 110: Conclusions Reached at the Third Meetings held on April 26th and 27th, 1918 in Paris," 28 April 1918; Allied Naval Council, "Memorandum No. 118: Report of the Third Meetings held on April 26th and 27th, 1918, in Paris," 6 May 1918, Box 545, RG45, NARA; Halpern, Mediterranean, 464-65.

87 Sims to Benson, 30 April 1918, Box 49, WSS, LC; Allied Naval Council, "Memorandums No. 140, 140A to 140E: Report of the Sub-Committee on Plans which met in Rome on May 15 th to May 21st, 1918," 1 June 1918, Box 545; Sims to Benson, 1 May 1918, Box 415, RG45, NARA. ${ }^{88}$ Allied Naval Council, "Memorandum No. 152: Conclusions Reached at the Fourth Meetings held on June 11th and 12th, 1918, in London," 15 June 1918; Allied Naval Council,

"Memorandum No. 158: Report of the Fourth Meetings held on June 11th and 12th, 1918, in London," 26 June 1918. Box 545, RG45, NARA.

${ }^{89}$ Cablegram draft Sims to OPNAV, 10 June 1918; Sims to OPNAV, 14 June 1918, Box 546; Nathan C. Twining to Benson, on "Allied Naval Council, submitting papers concerning," 20 June 1918, Box 544, RG 44, NARA.

${ }^{90}$ Navy Department, Planning, 245-54.
} 
Ultimately, the six months spent planning and lobbying effort served as a valuable exercise for the Planning Section and the Navy Department. The knowledge and experience gained by a group of planners plunging headfirst into coalition plans was itself invaluable for war and postwar application. That the actual Adriatic plan produced tangible results seemingly did not matter as much as demonstrating the Planning Section's utility and fulfilling presidential mandate.

Although the Planning Section's effort did not inflict any loss upon the k.u.k. Kriegsmarine, its work left an indelible mark on OPNAV. By the summer of 1918, OPNAV depended increasingly on the work of the London Planning Section for its own planning purposes in Washington. ${ }^{91}$ In mid-July 1918, Benson cabled Sims that he desired to continue planning work in Washington and requested the transfer of Yarnell to OPNAV, sending Sims Captain Luke McNamee in exchange. ${ }^{92}$ The CNO also requested that the London Planning Section prepare an outline of a planning organization based on recommendations from the war experience. ${ }^{93}$ In August, before Yarnell left to join OPNAV, Sims transmitted the Planning Section's memorandum no. 45 titled "Organization of a Plans Division for Navy Department."

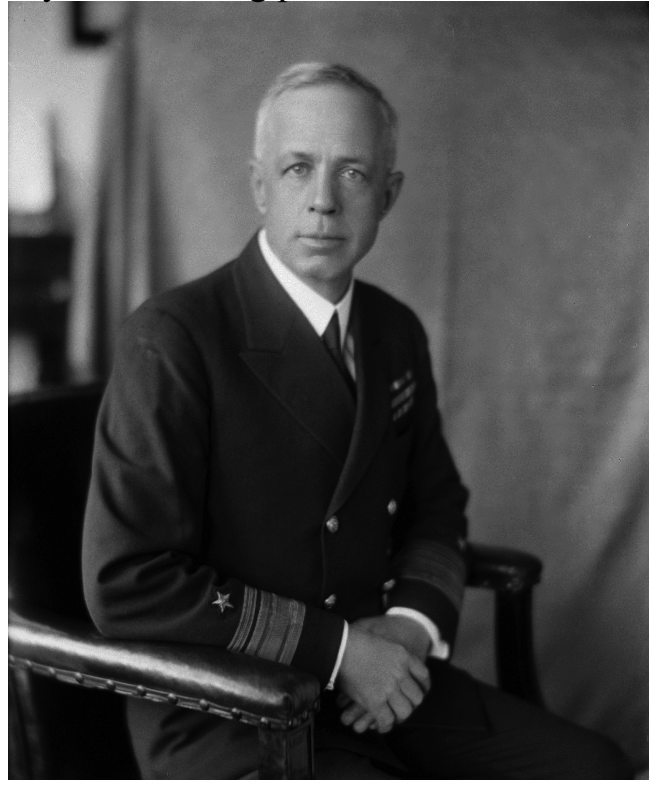

Rear Admiral Harry E. Yarnell, circa late 1920. Source: Harris \& Ewing Collection, Prints and Photographs Division, Library of Congress, Washington, DC

Discussing the methods of the American Planning Section and the Admiralty's Plans Division, the memorandum included a proposed organization for a Department of the Navy Planning Section within OPNAV of fifteen War College-trained personnel organized into five subject committees (policy, strategy, tactics, logistics, education) of three officers apiece to tackle assorted general problems. A list of nineteen problems was included with the memorandum. ${ }^{94}$

Benson became a solid supporter of both the Planning Section's potential and the capability of its personnel. During the postwar negotiations in Versailles, he brought Schofield and McNamee with him to Paris to study and draft memoranda

\footnotetext{
91 Naval Investigation, I: 1578.

92 Benson to Sims, 17 July 1918, Box 24, WSS, LC.

${ }^{93}$ Benson to Sims, 20 July 1918, Box 24, WSS, LC.

94 Sims to Benson, on "Forwarding Planning Section Memorandum No. 45, concerning Organization of Planning Division for Navy Department," 10 August 1918, Box 662, RG45, NARA; biographical file for Yarnell, NHHC; Navy Department, Planning, 311-318.
} 
on a variety of naval issues in conjunction with the peace negotiations. ${ }^{95}$ After returning to the US, the CNO in August 1919 launched a reorganization of OPNAV and established a Planning Division on 11 August, organized along enlarged lines of Memorandum Number Forty-Five, staffed with "capable youngsters with War College training and full of vim and vigor." ${ }^{.66}$ By 1922, the group reemerged as the War Plans Division, exclusively focussed on war plans. ${ }^{97}$

The First World War validated the establishment of the short-lived London Planning Section. From the intellectual underpinnings of study at the Naval War College, the Planning Section's work to develop a plan for offensive operations in the Adriatic equipped the American naval planners with experience and perspectives beyond the halls of academe. Perhaps, in hindsight, the Adriatic plan's greatest value to the US Navy is found in the interplay of coalition agendas and sea-land exigencies in war. If the Planning Section was itself an organizational innovation, one institutionalized postwar, the actual planners became catalysts for future interwar innovation. The operational knowledge and experience acquired by the planners in 1918 with the Adriatic plan and other endeavors would return to OPNAV, the Naval War College, and the US Fleet in the form of future war games, war plans, and tactical and operational developments. Although it took years to mature fully, the work begun by Sims, Pratt, Knox, Yarnell, and Schofield would ably prepare the US Navy for the next major conflict, and belatedly, the nation's maritime leaders of the twentieth century's first global conflict could bear witness to the aggressive offensive operations they so desired.

\footnotetext{
95 Navy Office of Information, Biographies Branch, "Rear Admiral Frank Herman Schofield, United States Navy, Deceased," 30 September 1963, biographical file for Schofield, NHHC; Frank H. Schofield to Dudley W. Knox, 24 December 1918, Box 673, RG45, NARA. McNamee was assigned to OPNAV's planning section on 18 December 1917 after Knox and Schofield had left. When Yarnell left Simsadus for OPNAV in August, McNamee in turn received orders to Simsadus in an even exchange of personnel, reporting in London on 21 September 1918. Henry P. Beers, "The Development of the Office of the Chief of Naval Operations, Part III," Military Affairs XI:2 (Summer 1947): 97-98.

${ }^{96}$ Naval Investigation, I: 684-93; Naval Investigation, II: 3293; Beers, “Chief, Part III," 98-99; Robert G. Albion, Makers of Naval Policy, 1798-1947, ed. Rowena Reed (Annapolis, MD: Naval Institute Press, 1980), 89-91.

${ }_{97}$ Klachko, Benson, 163-64; Edward S. Miller, War Plan Orange: The US Strategy to Defeat Japan, 1897-1945 (Annapolis, MD: Naval Institute Press, 1991), 82; Albion, Policy, 90-91.
} 